\title{
ARE COMPANIES IN THE CZECH REPUBLIC READY TO IMPLEMENT IFRS FOR SMEs?
}

\author{
L. Bartůňková
}

Received: August 31, 2012

\begin{abstract}
BARTƯŇKOVÁ, L.: Are companies in the Czech Republic ready to implement IFRS for SMEs? Acta univ. agric. et silvic. Mendel. Brun., 2012, LX, No. 7, pp. 39-44

The process of integration and globalization is closely related to the need for harmonization of accounting at international level. In this connection International Financial Reporting Standards (IFRS) have been developed, which are primarily designed for companies whose securities are traded on regulated markets of the European Union. However, as the importance of small and medium-sized entities has been recently on the increase, the International Accounting Standards Board (IASB) also issued after five years of effort in July 2009 the International Financial Reporting Standard for Small and Medium-sized Entities (IFRS for SMEs). At present, there is no legislation for the application of this standard in the Czech Republic or any other state of the European Union. Each jurisdiction must determine whether to adopt IFRS for SMEs, to what extent and for which entities the standard is mandatory and for which it is not. Already in previous years the European Commission analyzed data from surveys on this new standard and discussed its advantages and disadvantages. To date, however, it has not taken a single decision on whether to adopt and incorporate the standard into the European accounting legislation. The question also remains what attitude towards IFRS for SMEs companies operating in the Czech Republic will take. That is why this paper analyzes the opinions of some Czech companies belonging to the group of SMEs on the potential adoption of this standard.
\end{abstract}

IFRS, small and medium-sized entities (enterprises), harmonization, financial statements

An important feature of the contemporary European and world economy is multinational integration and globalization, which leads to the development of international capital markets and a larger number of multinational companies. In the economies of individual countries the share of foreign investments plays an increasingly important role and import and export of goods and services has become indispensable to the economy. In this context the need to harmonize financial reporting systems whose aim is to converge accounting principles and financing reporting in such a way that they become understandable for users in different countries has arisen. Financial statements provide important information not only for making qualified business decisions but also play an important role in giving subsidies, financial support and grants. The need for harmonization of accounting is gradually expanding beyond large business groups.
One of the most important systems of financial reporting, which is currently recognized in global financial markets, is International Financial Reporting Standards (IFRS). The requirements contained in IFRS are gradually implemented by individual countries into their national accounting legislation. The Czech Republic, for example, adopted in the year 2002 Regulation of the European Parliament No. 1606/2002 on the application of international standards, on the basis of which (starting from 1 January 2005) all accounting entities which are issuers of securities traded on regulated markets of the European Union must prepare and submit financial statements in accordance with IFRS. This regulation applies, however, only to a limited number of companies, and financial statements of a large majority of companies still remain without the necessary harmonization and the possibility of international comparison. 
In recent years attention has focused on small and medium-sized enterprises, which are of enormous economic importance for the development of the national economy. They are a major factor of economic growth, innovations, job creation and have a positive effect on reducing unemployment. Only in the Czech Republic in the year 2011 according to the Report on the Development of Small and Medium-sized Entities (2012) there were more than one million small and mediumsized enterprises, which represent $99.84 \%$ of all companies of the total number of active business entities.

However, small and medium-sized enterprises still show low participation in cross-border activities, which according to Bohušová (2007) is mainly due to distinct differences in tax systems of the countries and different systems of financial reporting. In this context it was necessary to harmonize accounting at the global scale also for small and medium-sized enterprises.

On 9 July 2009 the International Accounting Standards Board released the final version of International Financial Reporting Standards (IFRS) designed for use by small and medium-sized entities (SMEs). This was a step towards creating a condition leading to international comparability of financial statements of small and medium-sized enterprises at international level. At present, the decision of whether the standard will be adopted, to what extent and for which accounting entities it will be mandatory lies with each particular jurisdiction.

\section{MATERIALS AND METHODS}

The main objective of this paper is to evaluate the present attitude of small and medium-sized enterprises operating in the Czech Republic towards the possible future adoption of IFRS for SMEs. A partial objective was to analyze the advantages and disadvantages of the implementation of the standard. To fulfill the objectives standard scientific methods which are commonly used in papers on accounting were employed. These are predominantly description, analysis, interpretation, synthesis and deduction. Analysis of the advantages and disadvantages which are associated with the implementation of the standard is based on research conducted by the European Commission from November 2009 to March 2010. In the survey representatives of the users of financial statements, policy makers in the field of accounting and accountants preparing financial statements were invited to express their attitude towards the standard. The results of this analysis will be used to assess whether the results of the survey carried out by the European Commission considerably differ from the opinions of the respondents surveyed in the Czech Republic.

Another part of the paper is devoted to the evaluation of the current attitude of small and medium-sized enterprises operating in the Czech
Republic towards the possible implementation of the standard. The data needed for primary research were obtained through a questionnaire survey of selected companies (SMEs). Of about 200 companies contacted to express their views on IFRS for SMEs some 55 accounting entities responded which indicates quite high recoverability. The enterprises were chosen for the research survey according to the random sampling. These were mostly company executives, financial directors or accountants of the companies. Questionnaires containing a document with a brief description of the new standard were sending electronically from January until April 2012 to respondents. The open and polar questions enabled to the respondents express their personal opinions to the research scope. The evaluation of survey results was made by quantitative analysis which shows the distribution of opinion in the total number of answers. The data obtained were further used for the evaluation of the relationship between company size and the readiness of accounting entities to implement IFRS for SMEs. To measure the relationship of qualitative characteristics a test of independence in a contingency table was used. This test compares simultaneous frequencies $f_{i j}$ with theoretical frequencies which would be expected in the case of independence of characteristics. These theoretical frequencies are denoted $\mathrm{f}_{\mathrm{ij}}$. Then the relationship is

$$
f_{i j}^{\prime}=\frac{g_{i} \times h_{j}}{N},
$$

where $f_{i j}, i=1,2,3,4 ; j=1,2,3$ are so-called joint (or simultaneous) frequencies and

$$
g_{i}=\sum_{j=1}^{n} f_{i j}, \mathrm{i}=1,2,3,4
$$

or

$$
h_{j}=\sum_{i=1}^{m} f_{i j}, \mathrm{j}=1,2,3
$$

are marginal frequencies of both qualitative characteristics, and $\mathrm{N}$ represents the total number of surveyed enterprises.

For research the following hypotheses were chosen:

$\mathrm{H}_{0}$ : willingness to adopt and implement IFRS for SMEs does not depend on company size,

$\mathrm{H}_{1}$ : willingness to adopt and implement IFRS for SMEs depends on company size

Test criterion: $\chi^{2}=\sum_{i=1}^{m} \sum_{j=1}^{n} \frac{\left(f_{i j}-f_{i j}^{\prime}\right)^{2}}{f_{i j}^{\prime}} \sim \chi^{2}((m-1)(n-1))$.

If $\chi_{\exp }^{2}>\chi_{\mathrm{p}}^{2}((\mathrm{~m}-1)(\mathrm{n}-1)), \mathrm{H}_{0}$ is rejected at the selected significance level $p$. 


\section{RESULTS}

Because of the lack of tools for harmonization of financial reporting for SMEs, IASB launched in 2003 a project of development of IFRS for SMEs. The aim was to develop a standard that will be specifically designed for the needs of companies that are not subject to public interest and that prepare financial statements for the needs of external users. The external users can be companies' owners who are not involved in the process of business management, existing and potential creditors, rating agencies and others. An accounting entity is defined by the International Accounting Standards Board in IFRS for SMEs (2009) as public accountable if its debt or equity instruments are traded in a public market or it is in the process of issuing such instruments for trading in a public market (a domestic or foreign stock exchange or an over-the-counter market) or if one of its primary activities is holding assets in a fiduciary capacity for a broad group of outsiders and/or taking a deposit for a broad group of outsiders. This is typically the case for banks, credit unions, insurance companies, securities brokers/ dealers, mutual funds or investment banks.

After a series of discussions the standard was modified to its final form and on 9 July 2009 issued by the International Accounting Standards Board, thus creating a condition leading to the comparability of financial statements of small and medium sized entities at international level.

From November 2009 to March 2010 the European Commission published a document of IFRS for SMEs. During the comment period representatives of organizations and companies from Member States of the European Union and European accounting organizations could send their letters of comment. During this four-month period the European Commission received more than 200 responses from 26 Member States of the European Union and 4 countries outside the European Union. The consultation document contained a questionnaire which consisted of 12 questions as to whether it is appropriate to introduce financial reporting in accordance with IFRS for SMEs across Europe, what are the advantages and disadvantages of the introduction of a standard for reporting companies, what is the effect on their business relationships and what are the benefits to users of financial statements. Respondents were primarily preparers and users of financial statements, accountants and auditors, lawmakers and standard setters. The Czech Republic was represented by the Chamber of Auditors of the Czech Republic and the Ministry of Finance of the Czech Republic. The survey results revealed potential advantages and disadvantages associated with the adoption and subsequent implementation of the standard.

From the reactions of the respondents it can be concluded that IFRS for SMEs has a number of supporters in the European Union. They positively evaluate primarily the possibility to compile internationally comparable statements. Using the global financial accounting and reporting will ensure improvement in comparability and higher business efficiency across the border. Furthermore, the adoption of IFRS for SMEs may contribute to the establishment of new partnerships with foreign entities and encourage the company's international growth and subsequent control of international markets. The standard will, therefore, promote foreign trade and mergers and ensure lower costs of obtaining foreign capital. Creation of uniform rules for financial reporting also increases the mobility of accounting and auditing work. The adoption of IFRS for small and medium-sized enterprises is primarily supported by the companies that belong to international groups and the subsidiaries whose parent companies compile financial statements in accordance with "full IFRS". The preparation of consolidated financial statements in multinational groups will be easier and can reduce the cost of their preparation and follow-up audit.

Most respondents think that IFRS for SMEs is more suitable for large enterprises that are not issuers of securities traded on regulated markets of the European Union and medium-sized entities. In their view, the standard is still too complicated to use in small companies and reporting in accordance with it would considerably increase the cost of preparation of financial statements. Another disadvantage as perceived by respondents is in different national legal systems of the countries that hinder complete comparability of financial statements. Some of them also feel insecure about the future development of IFRS for SMEs in comparison with relatively stable national guidelines on accounting. Another significant disadvantage of implementation of IFRS for SMEs into the accounting systems of different companies can be high implementation costs.

Analysis of the advantages and disadvantages that are associated with the adoption and subsequent implementation of the standard was also performed by Turkish authors Arsoy and Sipahy (2009). The authors appreciate the possibility to prepare financial statements that are internationally comparable even within economic sectors. Other opportunities for businesses, as they point out, will be the potential domination of foreign markets and establishment of business combinations and cooperation agreements with foreign business entities. On the other hand, they fear that implementation costs will outweigh benefits and give rise to huge differences between the standard and the Turkish tax system. Financial reporting in Turkey is used for tax purposes and is conducted in accordance with business and tax regulations.

There are a few reasons why the company should prepare financial statements in accordance with IFRS for SMEs. Important are the objectives of the accounting entity and the practical needs of users of financial statements. In assessing whether to implement the standard the company should 
consider whether the benefits of the adoption of IFRS for small and medium-sized entities outweigh the implementation costs.

At present the use of the standard is not legally required in the Czech Republic or any other countries of the European Union. It depends on the decision of a particular jurisdiction whether the standard will be incorporated into the national accounting legislation, to what extent and for which businesses the standard will be mandatory. IASB has not set any quantitative criteria for defining companies which could be referred to as SMEs. This is mainly due to the fact that the standard is expected to be used both in the European Union and other countries worldwide and, therefore, it is impossible to create such quantitative criteria that would be suitable for all countries at the same time. Some countries in the world have already adopted IFRS for small and medium-sized entities and their experience is a valuable source of information for evaluating the suitability of adopting the standard in the Czech Republic and the whole European Union. These are predominantly the developing countries that do not have according to Sacho and Oberholster (2008) well-developed national standards and, therefore, they will accept IFRS for SMEs, which is suitable for global use, much more readily. One of these countries is, for example, South Africa, which adopted the standard as early as the year 2008 in the form of the then proposal.
Attitudes towards the potential implementation of IFRS for SMEs in the Czech Republic were captured through a questionnaire survey. The initial collection of data necessary for processing took place in the first quarter of the year 2012. The collection of data was carried out in a sample of 55 accounting entities classified as SMEs. Their representation is shown in Tab. I. The questionnaire survey, however, cannot be considered a representative survey because it is in its early stages and was conducted in a limited number of entities but complements opinions of respondents from other countries about the possible implementation of IFRS for SMEs.

The questionnaire was aimed at obtaining the following information: the object of business, company's participation in cross-border activities, satisfaction with the current state of national accounting legislation, willingness to adopt the harmonized system of financial accounting, and the expected benefits and barriers associated with the possible implementation of IFRS for SMEs.

The results of the survey conducted among small and medium-sized enterprises show that the possibility of preparing internationally comparable accounting statements is more likely to be welcomed by medium companies whose majority owner is a foreign company and whose important part of business is export and import of goods or services. These companies believe that using IFRS for SMEs would ensure easier reporting within the prepared consolidated financial statements. This

I: Representation of surveyed entities

\begin{tabular}{lccc}
\hline & \multicolumn{2}{c}{ Size of entity } \\
\cline { 2 - 4 } & micro & small & medium \\
\hline Number of surveyed entities & 20 & 26 & 9 \\
Number of foreign owned entities & 0 & 4 & 4 \\
Number of Czech owned entities & 20 & 22 & 5 \\
Number of entities that have already dealt with IFRS for SMEs & 4 & 8 & 8 \\
Number of entities that would prefer to prepare internationally comparable statements & 3 & 6 & 7 \\
Number of entities dissatisfied with the current national accounting legislation & 13 & 18 & 3 \\
\hline
\end{tabular}

Source: Author's own research

II: The results of the questionnaires

\begin{tabular}{|c|c|c|c|}
\hline Question & YES & NO & NO OPINION \\
\hline would increase credibility of business partners? & $50 \%$ & $34 \%$ & $16 \%$ \\
\hline would attract foreign investors to the company? & $17 \%$ & $66 \%$ & $17 \%$ \\
\hline ensure simpler reporting within consolidation groups? & $44 \%$ & $41 \%$ & $15 \%$ \\
\hline would facilitate the changeover on full IFRS? & $53 \%$ & $31 \%$ & $16 \%$ \\
\hline would facilitate obtaining of subsidies from foreign funds? & $37 \%$ & $47 \%$ & $16 \%$ \\
\hline would lead to improvement of administration demandingness? & $79 \%$ & $0 \%$ & $21 \%$ \\
\hline would increase the implementation costs? & $62 \%$ & $13 \%$ & $25 \%$ \\
\hline
\end{tabular}

Source: Author's own research 
argument also supports testing the dependence of qualitative characters from which it follows that there is a relationship between the size of the accounting entity and the willingness to implement IFRS for SMEs. The larger the entity is, the higher the willingness to implement the standard.

The facts that speak against the introduction of the standard in the Czech Republic are predominantly concerns over the greater administrative burden, high implementation costs and unadjusted relationship between the earnings reported under IFRS for SMEs and the tax base of income. The entities surveyed would appreciate it if in the event of the future adoption of the standard the calculation of the tax liability was based on the earnings reported under this standard. The main factor that considerably reduces the willingness of Czech small and medium-sized companies to prepare financial statements in accordance with IFRS for SMEs is a lack of knowledge of this standard. According to the responses obtained $63 \%$ of respondents had never met with IFRS for SMEs and mainly because of this obstacle they are not qualified enough to identify the potential benefits associated with its implementation. The Tab. II deals with the opinions of respondents on reporting according to the IFRS for SME.

\section{DISCUSSION}

Despite the fact that small and medium-sized enterprises represent a decisive proportion of companies operating in Member States of the European Union and other countries of the world, their systems of financial reporting vary with jurisdictions. For this reason, it is suitable to encourage the introduction of a single financial reporting framework for companies referred to as SMEs. One of good solutions for them may be the incorporation of IFRS for SMEs into their national accounting legislation.

At present there are a lot of views on the adoption of the standard in various countries of the world. The attitude of developed countries towards the adoption of the standard is rather cautious because they consider the existing system of financial reporting to be quite good. Some developing countries, which lack their own accounting systems, incorporated this system into their national legislation already in the past. This is, for example, South Africa which adopted the standard in the year 2008 in the form of the then proposal.

Readiness to implement IFRS for SMEs into the Czech accounting system of small and mediumsized entities, according to the questionnaire survey, depends on the size of the company and its involvement in cross-border activities. Companies whose majority owner is a foreign company can see in the adoption of IFRS for SMEs the option to prepare reporting more easily within their consolidation groups. On the contrary, microentities that prepare their financial statements predominantly for tax purposes are worried about higher administrative burden and cannot see any benefits in reporting in accordance with IFRS for SMEs.

Views similar to those of the respondents surveyed in the Czech Republic can be found also among respondents from other European Union countries. Their attitude towards the implementation of IFRS for SMEs is not uniform at all. The idea of implementation within the European Union as well as in the Czech Republic is favoured predominantly by medium-sized and large entities that have their parent and subsidiary companies in different Member States and also by companies seeking international funds.

The possibility of using a harmonized and highquality system of financial reporting may lead to increased clarity, transparency and comparability of financial statements at international level, which could help to attract potential foreign investors and start new business partnerships. On the other hand, the company adopting IFRS for SMEs has to be aware of high implementation costs, which include costs for the introduction of new information technologies, implementation of a new management system and training of the staff involved in the preparation of financial statements. These costs will be incurred whenever there is a revision of the standard.

Readiness to implement the standard is also closely related to the link between accounting and tax rules. Countries where there is a close link between the pre-tax income and the tax base are less willing to implement the standard. An example can be according to PricewaterhouseCoopers (2004) Germany where unified financial statements are prepared for financial reporting and tax purposes. The adoption of IFRS for SMEs in this country would push up the costs of preparation of the financial statement because it would be necessary to keep two accounting systems - one in accordance with IFRS for SMEs and the other in compliance with national accounting legislation, which is essential for the calculation of the tax base. It can be assumed that if there is a link established between IFRS for SMEs and tax legislation in the future, the standard will become attractive for the greater part of small and medium-sized enterprises because the need to prepare duplicate statements will disappear.

At present, there is still no considerable experience with the adoption of the standard on the basis of which some relevant conclusions could be derived. Therefore, it is difficult to determine whether the benefits, which are, moreover, hard to quantify, outweigh the costs, which are connected with the implementation of IFRS for SMEs. Even though there is now an important tool of harmonization of financial reporting of small and medium-sized enterprises, the question remains whether it will be properly used. Provided the standard is not adopted by all states in the future, the purpose of IFRS for SMEs will not be met and financial statements of 
a large proportion of companies will remain without a chance of international comparison. Individual states should, therefore, allow enterprises optional implementation of the standard and should not insist on its mandatory implementation. The possibility of using the existing national accounting system should be maintained especially for accounting entities operating only in the domestic market and also for micro-enterprises which prepare financial statements predominantly for tax purposes. For this reason, the best solution seems to be to apply a three-tier accounting framework, which would include reporting under full IFRS, IFRS for SMEs and reporting in accordance with national accounting legislation.

\section{SUMMARY}

Creating a single financial reporting system in the form of IFRS for SMEs is certainly a positive step towards achieving comparability of financial statements of SMEs at international level.

The results of the survey held by small and medium-sized enterprises operating in the Czech Republic show that willingness to implement this new standard into the national accounting system depends mainly on the size of business and its involvement in cross-border activities. Businesses that operate only at the local level and prepare their financial statements only for tax purposes are worried about the high administrative costs that accompany financial reporting in accordance with IFRS for SMEs. Like the results of the questionnaire survey also the survey held by the European Commission in May 2010 revealed a relatively small interest of Czech entities in the process of harmonization of financial reporting by small and medium-sized companies.

At present, the application of IFRS for SMEs in the Czech Republic or any other country of the European Union is not legally required and thus it depends on the decision the specific jurisdiction whether the standard will be adopted and to what extent. When deciding on adoption of the standard, experience with the standard in the countries where adoption took place in past years will play an important role. As the Commission has not yet taken unified position to IFRS for small and mediumsized enterprises, it can be assumed that the issue of adoption of IFRS for SMEs will be addressed by the European Union in the near future.

\section{Acknowledgement}

This paper was prepared within the grant project IGA No. 14/2012 The impacts of application of new reporting methods of leases on chosen indexes in financial analysis sponsored by the Internal Grant Agency at Mendel University in Brno.

\section{REFERENCES}

ARSOY, A. P., SIPAHI, B, 2009: International financial reporting standards $x$ for small and medium sized entities and the Turkish case. Ankara Universitesi SBF Dergisi, pp. 62-64.

BOHUŠOVÁ, H., 2007: The Possible Ways to IFRS for SME Development. In: Acta Universitatis Agriculturae et Silviculturae Mendelianae Brunensis, ISSN 1211-8516.

EUROPEAN COMMISION, 2010: Summary Report of the responses received to the Commissions's Consultation on the International Financial Reporting Standard for Small and Medium-sized Entities. [online] [cit.201201-11] Dostupné z http: //ec.europa.eu/internal_ market/accounting/docs/ifrs/2010-05-31_ifrs_ sme_consultation_summary_en.pdf.

IASB, 2009: International Financial Reporting Standard for Small and Medium-sized Entities [online] [cit.2012-01-06] Dostupné z http://www.ifrs.org/ IFRS+for+SMEs/IFRS+for+ SMEs.htm.

MINISTERSTVO PRŮMYSLU A OBCHODU ČR, 2012: Zpráva o vývoji malého a středního podnikání a jeho podpoŕe $v$ roce 2011. [online] [cit.201208-15] Dostupné z http://www.mpo.cz/ dokument105614.html.

NERUDOVÁ, D., BOHUŠOVÁ, H., SVOBODA, P., ŠIROKÝ, J., 2009: Harmonizace účetních standardi̊ pro malé a střední podniky. Wolters Kluwer ČR, 272 s. ISBN 978-80-7357-500-7.

PRICEWATERHOUSECOOPERS, 2004: Vazby mezi daní z príjmu právnických osob a účetním výkaznictvím pro Českou republiku. [online] [cit.2012-01-10] Dostupné z http://www.mfcr.cz/cps/rde/xbcr/ mfcr/Vazby_mezi_dani_a_ucetnim_vykaznictvim. pdf.

SACHO, Z. Y., OBERHOLSTER, J. G. I., 2008: Factors impacting on the future of the IASB. Meditari Accountancy Research, Vol. 16, pp. 117-137.

Address

Ing. Lucie Bartůňková, Ústav účetnictví a daní, Mendelova univerzita v Brně, Zemědělská 1, 61300 Brno, Česká republika, e-mail: xbartunk@node.mendelu.cz 